\title{
The Turkish Economy at the Crossroads: The Political Economy of the 2018 Financial Turbulence
}

\author{
NURULLAH GÜR*, MEVLÜT TATLIYER, ${ }^{*}$ and ŞERIF DiLEK ${ }^{* *}$
}

ABSTRACT In 2018, the Turkish economy suffered one of the most severe financial speculations in its 38-year open economy era. Some have tried to explain the causes of the financial turbulence solely by linking it to the deterioration in the macroeconomic indicators, such as the inflation rate and current account deficit. However, this approach cannot help us to understand the fundamental causes of the financial turbulence. This paper argues that internal and external shocks ranging from the coup attempt in 2016 to geopolitical risks hindered the designing and implementation process of the second-generation reforms Turkey needed to escape from its middle-income trap. As the reform process slowed down and the severity of shocks increased; uncertainties over economic performance and policies mounted. This uncertain environment paved the way for financial turbulence by providing opportunities for speculators to mislead the markets in line with their own interests.

\section{Introduction}

n 2018, the Turkish economy underwent one of the most severe financial speculations of its history. The U.S. dollar/Turkish lira exchange rate climbed from 3.75 to 4.90 in the first five months of 2018, the lion's share of the increase coming in May. The lira faced an even harsher depreciation in August as the exchange rate peaked at 7.22, before decreasing gradually below 6.00 .

Although many posited that the currency shock emanated mainly from high levels of current account deficit and inflation, this "economic" explanation is clearly not enough, particularly for a country such as Turkey with its considerable economic strength and the level of its financial depth. ${ }^{1}$ In order to explain the sudden and severe volatility in the exchange rate, the following factors should also be taken into account: the constant crisis-mongering to create a perception that economic governance would be disrupted after Turkey's transition to a presidential system, the manipulations with regard to foreign exchange markets, the banking sector, and the financial speculations fed by the then strained relations between Turkey, and the United States (U.S.). ${ }^{2}$

* İstanbul Medipol University, Turkey

** Kırklareli University, Turkey

Insight Turkey Vol. 21 / No. 4 / 2019, pp. 135-160 


\section{Although many posited that the currency shock emanated mainly from high levels of current account deficit and inflation, this "economic" explanation is clearly not enough, particularly for a country such as Turkey with its considerable economic strength and the level of its financial depth}

Turkey is not unfamiliar with exchange rate shocks and financial crises. The 2000-2001 economic crisis, which emanated mainly from the flawed economic policies of incompetent coalition governments along with the political and financial hangover of the "post-modern coup" of February 28, 1997, in the Turkish economy, as well as uncontrolled globalization, still has a prominent place in people's memories. The Turkish economy weathered the destructive effects of this crisis and made significant progress thanks to the political stability following the 2002 elections and resulting economic/financial reforms. The GDP per capita has more than tripled to around $\$ 10,000$ and public debt as a percentage of GDP declined markedly from around 70 to 28 percent. Inflation rate retreated to single-digit levels sustainably after 34 years of very high rates, while exports skyrocketed from $\$ 36$ billion to more than $\$ 168$ billion. The Turkish industry sector has also expanded dramatically. Between 2002 and 2017, the industry sector grew by 163 percent, significantly surpassing overall economic growth, which stood at 131 percent. The share of the industry sector in the economy increased from 17.7 to 20.1 percent. ${ }^{3}$ Moreover, the banking sector has grown substantially as the credit volume to GDP ratio, which averaged 18 percent between 1980 and 2002, expanded forcefully from 13.3 percent in 2002 to 45.3 percent in 2010, and 64.7 percent as of $2018 .{ }^{4}$ As a result of these developments, the finance industry grew by 287 percent and its share in the GDP widened from 2.6 to 4.2 percent between 2002 and 2018. ${ }^{5}$ Alongside the financial deepening, the banking sector has also grown significantly stronger on many key indicators, including capital adequacy ratio, non-performing loan ratio, the level of credit portfolio diversification and profitability. Note that in this period the research and development spending to GDP ratio has more than doubled and poverty has almost been eliminated thanks to high growth performance and higher levels of social spending. ${ }^{6}$

While the Turkish economy has been on a markedly rising trend since 2002, Turkey encountered a series of severe internal and external shocks. The 20082009 global financial crisis, the long-lasting shockwaves in the aftermath of the so-called Arab Spring (particularly the Syrian civil war), the Gezi Park events, the December 17-25 “judicial coup" attempt, the PKK and Daesh-led terrorist attacks, most prominent being the July 15 military coup attempt in 2016, and finally the financial attacks in 2017 and 2018 have all had markedly adverse 
effects on the Turkish economy. Despite all of these and to the astonishment of many, Turkey remained the third fastest growing country behind China and India among the G20 between 2013 and 2018.

This article aims to analyze the financial turbulence that Turkey experienced in 2018 from a political economy perspective. The second section briefly summarizes the course of the Turkish economy from the 2000-2001 economic crisis to the 2008-2009 global financial crisis, in order to better understand the financial and economic pillars that the Turkish economy has been built on, particularly with the help of the first and second-generation reforms. The third section discusses how, and in what ways, Turkey tried to achieve a new success story by implementing second generation reforms after the 2008-2009 global financial crisis, only to be hampered markedly by politically motivated internal and external shocks since 2013. The fourth section focuses on the developments before and after the financial turbulence in 2018. The fifth section discusses economic and financial vulnerabilities Turkey needs to eliminate, or mitigate, in order to have a stronger economic base and financial structure and to be able to withstand possible financial turbulences in the future. The sixth section concludes with a general assessment.

\section{Turkey's Economy from the 2000-2001 Crisis to the Global Financial Crisis}

In the 1990s, political instabilities and bureaucratic incapacity resulted in recurrent political and economic crises in Turkey. The rapid and uncontrolled financial liberalization without a solid regulatory framework, the siphoning-off of the public resources by unregulated banks and many others, and the "post-modern coup" of February 28, 1997, severely damaged the Turkish economy and triggered the 2000-2001 economic crisis. ${ }^{8}$ This macroeconomic predicament resulted in yet another Turkey-IMF deal.

The constituents' anger towards the politicians caused a tectonic shift in Turkish politics with the 2002 general elections, as unprecedentedly all political parties that had been in the parliament before the elections could not pass the 10-percent threshold and were left out. As the winner of the elections with a clear majority in the parliament, the then one-year old AK Party formed a single-party government in 2002. The AK Party had taken over an economic wreck of chronic inflation, massive public debt, and an eviscerated banking sector with a malfunctioning and underperforming real economy, not to mention high levels of poverty and income inequality. ${ }^{9}$

As a result of the first-generation economic reforms made by the AK Party, along with the favorable global conditions in terms of risk appetite and liquid- 
As Turkey was trying to upgrade its economic structure and potential, the financial crisis that erupted in the U.S. spread all over the world in a relatively short time with devastating results making the 2008-2009 global financial crisis (GFC), by far the worst one since the global economic crisis of 1929 ity, the Turkish economy successfully bounced back from the crisis and recovered rapidly. It moved even considerably further with the elimination of important long-term structural problems such as chronic inflation, under-regulated banking systems, and high levels of public debt thanks to the reconstruction of the banking sector, tight monetary and fiscal policies, and various economic reforms. ${ }^{10}$

Turkey had suffered from very high inflation rates (more than 50 percent on average), from the 1970s to the 2000s because of a vicious cycle consisting of fiscal profligacy, monetization of the government debt to a high degree, and very high interest rates that increased the debt burden even further. After this cycle had been shattered in 1997 by the elimination of monetization through a protocol signed between the Turkish Treasury and the Turkish Central Bank (TCMB), it was greatly reduced thanks to the fiscal discipline achieved under the AK Party rule during the 2000s. ${ }^{11}$ Furthermore, the TCMB adopted an inflation-targeting regime with a firm, and sometimes excessive, commitment to price stability and low inflation rates in 2002. As a result of these developments, inflation rates in Turkey decreased to one-digit levels, averaging 8.2 percent between 2004 and 2017.

While the Turkish government pursued a tight fiscal policy and achieved fiscal discipline as part of the IMF deal, it also increased social spending considerably in almost all areas, particularly health and education, resulting in a much-expanded and deepened social policy base. ${ }^{12}$ This situation differentiated Turkey as a success story among countries who had signed stand-by agreements with the IMF. This positive dissociation was completely meaningful, because while the IMF prescribed that the Turkish government should cut down spending in almost all areas, the government took the other way and expanded social spending decisively. To put it another way, Turkey achieved economic stability and inclusive growth at the same time by implementing market-friendly policies, countercyclical Keynesian economic policies, and social policies. ${ }^{13}$

Alongside the marked amelioration of the macroeconomic outlook, the steps taken along the EU membership process and the democratization of the public sphere caused a significant improvement in foreign investors' confidence in Turkey. ${ }^{14}$ The Turkish economy, capitalizing on the favorable global liquidity conditions, successfully attracted foreign investments at record levels. Along 
with this, TCMB's extremely tight monetary policy and the strong inflow of foreign capital resulted in a significantly overvalued lira. Despite this, Turkish exports rose tremendously thanks to the strong emphasis and financial support for exports in various dimensions by the government as well as a proactive foreign policy approach with a view to find new markets around the globe. ${ }^{15}$

On the other hand, when this economic/financial transformation was happening, the AK Party had to engage in a political struggle as the elected-government with undemocratic forces in the judiciary and military, where bureaucratic and military tutelage was still strong, and held the conviction that they were "ruling the roost." The "e-memorandum" submitted by the military against the government, the high-court decision (famously known as the "367 crisis") to prevent the parliament from electing the president, and ultimately the closure case of the AK Party (it avoided being banned by just one vote in the Supreme Court), were the most important attempts to keep the government from functioning, even to eliminate it, and let the continuation of the bureaucratic and military tutelage.

\section{From the Global Financial Crisis to Financial Turbulence}

In the first five years of the AK Party rule, the Turkish economy bounced back from the "lost decade" of the 1990s and the 2000-2001 crisis with impressive growth rates thanks to political and financial stability achieved, significant improvements in the ease of doing business, first-generation economic reforms, marked productivity increases via FDIs and nascent SMEs and export incentives.

In order to steadily grow, avoid the middle-income trap, and take its place among the league of developed countries, Turkey had to achieve much more than what had been done so far. ${ }^{16}$ In other words, Turkey had to write a new economic success story that would trigger long-run sustainable economic growth. Strategies and targets such as the implementation of selective industrial and agricultural policies, the shift towards high-tech manufacturing, diversification of export markets, and financial deepening form the basis of this new story. ${ }^{17}$

As Turkey was trying to upgrade its economic structure and potential, the financial crisis that erupted in the U.S. spread all over the world in a relatively short time with devastating results making the 2008-2009 global financial crisis (GFC), by far the worst one since the global economic crisis of $1929 .{ }^{18}$ Deeply integrated into the global economy, the Turkish economy was also negatively affected by this crisis. It first came to a near standstill in 2008 with a growth rate of just 0.7 percent and contracted by 4.7 percent in 2009 . However, 


\section{The immediate aftermath of the coup attempt was a significant test for the Turkish economy. Turkey managed to overcome the difficulties with incredibly little damage as both the government and the business world stood firm}

In the aftermath of the GFC, the Fed, i.e., the U.S. central bank, pursued rather an expansionary monetary policy in an effort to invigorate the U.S. economy. Other major central banks such as the European Central Bank (ECB), Bank of Japan (BoJ), and Bank of England (BoE) followed the Fed in that regard and implemented considerably loose monetary policies. Thus, in this period, the liquidity injected into the national and regional economies found their way to developing countries such as Turkey, considerably in the search for higher yields. Foreign capital, which flowed to Turkey in abundance in this period, ${ }^{20}$ had a considerable share in the high economic growth rates achieved in those years.

However, a rather positive outlook in the Turkish economy was increasingly overshadowed by various political developments. The judicial processes of the Ergenekon and Balyoz cases forced the government to divert a significant amount of its attention and energy to this area after 2010. In addition, an important referendum in regards to changes in the constitution took place in 2010 and was accepted with a "yes" vote of approximately 58 percent of the voters. The constitutional transformation, which took place on the $30^{\text {th }}$ anniversary of the 1980 coup and removed an important chunk of the undemocratic components installed by putschists from the constitution, marked a watershed moment in Turkey. The changes in the constitution, which was reached by a strong societal consensus, helped form the conviction, in the society at large, that the construction of a "new Turkey" with all of its positive connotations was on the way.

This significant step on the way of democratization gave hope to Turkey for the second-generation reforms to be implemented for further economic development, a possible continuation of the first-generation reforms, which resulted in macroeconomic stability and considerable economic progress after the 20002001 economic crisis. However, the government was growingly distracted and the political process in Turkey was considerably distorted by various undemocratic interventions, including the Gezi Park events, the "judicial" coup attempt of December 17-25, 2013, the attacks of terrorist organizations such as the PKK and Daesh, the coup attempt of July 15, 2016, and financial attacks against the Turkish economy since 2016, not to mention the harsh anti-Turkey stance of the West at large. These interventions kept Turkey considerably 
away from engaging in the "structural" second-generation reforms necessary for further economic progress. ${ }^{21}$

The outlook of the Turkish economy was rather good in the first months of 2013, which was reflected in the historically low interest rates of around 4.6 percent. The Turkish stock market index also boomed to historically high levels of about 93,000. Moreover, another historical moment in May 2013, Turkey cleared its debt to the IMF totally by paying the last installment of the loan taken from the IMF as part of the stand-by agreement of 2005. However, this positive outlook was significantly clouded by the Gezi Park events in June and the "judicial" coup attempt in December 17-25.

The Gezi Park events started as an environmental protest against the reconstruction of a historical building as an effort to save the park and the trees in it. However, these events quickly devolved into a revolt against the government as extremist groups in the park started to become predominant in the protests. In the beginning it was an innocent movement, but it soon became a highly non-democratic, anarchic, and even violent movement that no government could tolerate. Even one of the poster boys of the Gezi Park events declared openly that the real issue was not about trees, clearly implying that it was about toppling the government. ${ }^{22}$ In an effort to come to a possible common understanding, the then government, arranged a meeting and listened to the demands of the protesters. However, the demands of the protesters went considerably beyond what was rational: they demanded the cancellation of mega projects such as the "third bridge," "third airport," and "Canal İstanbul," which were and are of utmost importance for the Turkish economy. ${ }^{23}$ The general public opinion in regard to the events increasingly soured and eventually turned into outright contempt with these indefensible demands alongside the violence and anarchy in the Gezi Park. As a result of the rapidly deteriorating public opinion and from the strong stance of the then government, these protests gradually waned and eventually died out without any tangible result. ${ }^{24}$ However, the Gezi Park events took their toll on the Turkish economy, as the Turkish stock market index in terms of the U.S. dollar declined by 40 percent in value and interest rates (government bonds) skyrocketed from 4.6 to around 8 percent within just 15 days. $^{25}$

Then came the December 17-25 “judicial” coup attempt, in which FETÖ (Gülenist Terrorist Organization) tried to discredit the then government by allegations of corruption via its members that had infiltrated the judiciary and the police. With this coup attempt, not only the government but also the public in general came to understand that the so-called "Hizmet movement" was not a peaceful religious organization, but an illegitimate sect with a secret political agenda, hence, a threat to national security. It became evident in those days that FETÖ, which had been infiltrating the state for more than 30 years, was 
expecting to assume power when the time came.

The "judicial" coup attempt took its toll on the Turkish economy, too. In the aftermath of this attempt, the total value of companies listed in the Turkish stock exchange market declined by $\$ 49.3$ billion, and the net outflow of foreign capital amounted to $\$ 238$ million. ${ }^{26}$ The TCMB tightened its monetary policy to a great extent and increased the policy interest rate from 4.5 to 10 percent in just one move as a result of the political turmoil Turkey was experiencing. ${ }^{27}$ Although the policy interest was gradually reduced to 7.5 percent, the tight monetary policy caused the Turkish economy to operate below its potential for a considerable time. ${ }^{28}$ In the wake of the political turmoil, the local elections held in March 2014 and the subsequent presidential election in August 2014 clearly showed that the public in general sided with political stability under the then government. Moreover, terrorist organizations such as the PKK and Daesh intensified their attacks in Turkey from 2015 onwards. Between July 20, 2015 and December 31, 2016, the PKK conducted no less than 817 attacks in Turkey, ${ }^{29}$ while between March 2014 and October 2016 Daesh conducted 14 major terrorist attacks, causing 304 deaths and 1,338 people wounded. ${ }^{30}$ The terrorist attacks and growing instability in Syria at that time also took its toll in the Turkish economy as they marred economic activity, diminished tourism revenues, and decreased exports. ${ }^{31}$ In a nutshell, the Gezi Park events, December 17-25 "judicial" coup attempt and terrorist attacks kept Turkey considerably from focusing on the economic reforms it needed to in order to increase efficiency and productivity. ${ }^{32}$ It also needs to be remarked that the Fed's announcement in 2013 regarding a gradual tightening of monetary policy after years of an extremely loose and "unconventional" one drove investors away from developing countries such as Turkey to an extent. ${ }^{33}$ Over the years, this worsening of investors' mood towards emerging markets had negative effects on the Turkish economy.

Meanwhile, feeling uncomfortable with the ambivalent attitude and policies of the West in general towards terrorism, Turkey adopted a different foreign policy stance and distanced itself from its traditional allies to an extent. However, this partial switch should be evaluated not as an axis shift in foreign policy as argued by some circles but as an attempt to create a rational, pragmatic and results-oriented strategy that can reasonably culminate in alternative collaborations and partnerships with non-Western states, since Turkey has di- 
In the absence of an economybased explanation, it must have been political factors, i.e. the political tensions between the U.S. and Turkey over issues like FETÖ, the Syrian war, the S-400 agreement, and the Brunson case, that were behind the financial attacks and hence the severe depreciation of the lira rectly been affected by the most important global developments and should come to terms not just with Western countries such as the US, Germany or France, but also with Eastern countries such as Russia, Iran, Saudi Arabia, Azerbaijan or China. ${ }^{34}$

After infiltrating intensively almost all the bureaucratic mechanisms of the state, including the judiciary, the police, and the army, FETÖ attempted a military coup on the night of July 15, 2016, to wrest control of the country. This attempt was thwarted first and foremost by the people of Turkey, who did not hesitate to take to the streets in large numbers to confront and fight the Gülenist junta on that night. The firm stance of President Recep Tayyip Erdoğan and other political figures was also instrumental in the prevention of the coup attempt. ${ }^{35}$

The coup attempt was also a serious challenge for the Turkish economy, since coups or coup attempts can be regarded among the biggest political risks a country can ever face. Therefore, the immediate aftermath of the coup attempt was a significant test for the Turkish economy. Turkey managed to overcome the difficulties with incredibly little damage as both the government and the business world stood firm; the former strove to mitigate the possible negative effects of the coup attempt in the economy by various expansionary economic policies and the latter tried to operate as usual. The economic stance of the public was also critical in this successful performance, as they did not panic or significantly cut down on their expenditures in the immediate aftermath of the coup attempt. ${ }^{36}$ The stimulus packages offered by the government to the real sector and the tax deductions provided to households contributed positively to both the GDP and employment. Moreover, with the aim of supporting the real sector's access to finance, the government expanded the scope of the Credit Guarantee Fund (CGF) in 2017. To avert the possible negative effects of the coup attempt on the economy, the government tried to support the real sector by greasing the wheels of the credit market. Revitalizing the CGF was perhaps the most important step in this context. Easing access to finance for SMEs through the CGF was initially an immediate move to avoid a potential economic slowdown, rather than being part of a long-term strategy. But after a while, the government announced that the CGF would be used as a strategic policy tool to finance firms and sectors that are promising in term of increasing high-value added products and exports. ${ }^{37}$ 
It should be noted that the credit rating agencies S\&P and Moody's hastily downgraded Turkey's rating right after the coup attempt,${ }^{38}$ although Turkey showed a strong resistance against the coup attempt both politically and economically, which would result in a positive economic performance and outlook in 2017. Conflating political issues with economic and financial dynamics to such an extent raised suspicions regarding the objectivity of ratings given and of assessments made by the international credit rating agencies. International media outlets based in the U.S. and Europe were not exempt from this suspicion as they increasingly adopted a bitter anti-Turkey stance in recent years. $^{39}$

The Turkish economy grew by 7.4 percent in 2017, despite regional and global instabilities, such as the extended civil war in Syria, the independence referendum brought up by the Kurdistan Regional Government (KRG) in Iraq, the Qatar crisis that upset the balance of the Gulf, and the political instability in the Saudi royal family, alongside, of course, the coup attempt in the previous year. Moreover, the increasingly tense relations of Turkey, with particularly the U.S. and also the EU, put the country in a constant state of crisis management. ${ }^{40}$ The disagreements between Turkey and the U.S., such as the FETÖ case, the U.S. support to the PYD-YPG in Syria, the Zarrab case, the visa crisis, the U.S. decision to recognize Jerusalem as Israel's capital, and the Pastor Brunson case, played their parts in the deteriorating relations between the two countries. The financial attacks against Turkey in 2017 and 2018 were direct ramifications of these tense relations.

\section{External Shocks Paving the Way for Financial Turbulence}

The criticisms that Turkey distanced itself from the growth- and development-friendly economic reforms and the EU norms ${ }^{41}$ are weak as they lack a political economy perspective both at the national and international level. Internal and external political developments such as the coup attempt, terrorist attacks, and growing geopolitical risks have had the inescapable effect of diverting Turkey's attention considerably away from second-generation economic reforms such as forming a comprehensive, visionary, and performance-based incentive system for the real sector, improving the education system, deepening financial sector, and strengthening the capital markets further.

Moreover, the stagnation of Turkey's EU accession process stemmed mainly from the EU and the increase in populism in Europe along the lines of the far right in the aftermath of the GFC. EU countries and institutions continuously disappointed Turkey when it came to issues such as the Cyprus referendum, Syrian refugees, the PKK, and FETÖ. Many European politicians embraced an "EU without Turkey" attitude with an excessively confrontational stance 


\section{Overall excessively welcoming and accommodating approach to foreign capital between 2002 and 2014 resulted in the overvaluation of lira to the order of 60 percent and massive expansions in current account deficit}

against Turkey usually for shortterm political gains. Meanwhile, Turkey's enthusiasm for entering the EU diminished markedly as the viability of the EU project after the GFC has been damaged significantly by the Greek crisis, Brexit, and the rise of the far right in Europe, alongside the EU's existing drawbacks such as an aging population and the stagnating economy.

Having overcome a number of obstacles, Turkey grabbed the opportunity to initiate needed political and economic reforms through a better-organized and visionary presidential system after the April 2017 referendum and the June 2018 snap elections. However, the deep financial attacks against Turkey became the main challenge with which the government had to deal. In other words, short-term challenges once again trumped long-term issues in Turkey.

Between May and August 2018, Turkey suffered one of the most severe exchange-rate fluctuations in its history. Turkey had experienced three major speculative attacks in 2016 and 2017 (the first in November 2016, the second in January 2017, and the third in October-November 2017). Yet, even these earlier attacks pale significantly in comparison to the speculative attacks in $2018 .{ }^{42}$ The U.S. dollar/Turkish lira exchange rate skyrocketed from 3.75 in December 2017 to an incredible 7.22 in August 2018.

The Turkish economy and public finances were not in such a bad shape as to trigger such a severe fluctuation in the exchange-rate markets. Nor did the government discard fiscal discipline because of the elections, unlike some international analysts argued as a possible cause of soaring volatility. On the contrary, the general economic framework in Turkey has remained considerably good. Fiscal discipline has always been maintained during AK Party governments, even in the election years. Actually, the government succeeded in preserving fiscal discipline despite having endured serious political challenges including a coup attempt and having experienced seven elections since 2013. As a result of this stern stance, Turkish public debt to GDP ratio has been one of the lowest in the world.

Moreover, contrary to what was posited by some observers, the transformation of the political system did not result in a deviation from free-market norms in Turkey. Despite some concerns that the Central Bank would lose its independence after the elections, it did not refrain from aggressively increasing interest rates when it deemed necessary. It is thus difficult to attribute the sudden and 


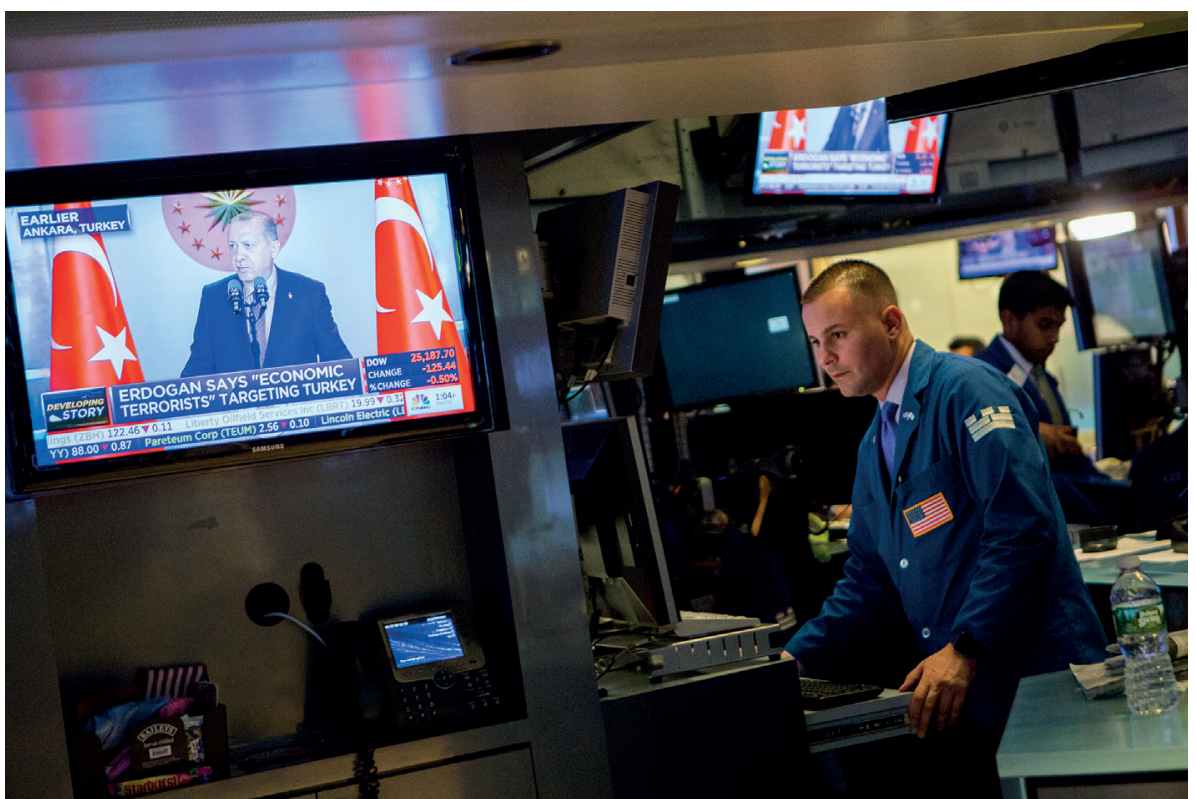

sharp fluctuations in the currency market to solely the concerns about monetary and fiscal policy. ${ }^{43}$

In fact, as a result of the highly fluctuating global economy and finance over the past decade, many countries such as Turkey have faced certain macroeconomic problems, which included high levels of current account deficit and the reemergence of double-digit inflation rates after a long time. After the staggering events of 2016, the Turkish economy grew more than its potential in 2017, causing the current account deficit to rise. As Turkey is considerably dependent on external sources for energy and intermediate goods, it experiences a rise in current account deficit during the periods of high economic growth. Hence, the rising cost of imported intermediate goods due to depreciation of the lira as well as some of the structural problems in agriculture and food supply chains caused a mild increase in inflation in 2017.

However, neither the worsening of the current account deficit nor increases in the inflation rate can explain such a jump in volatility in the exchange rate in such a short period of time. Within this framework, it is not easy to explain the depreciation of the lira in 2018 in economic terms. ${ }^{44}$ In the absence of an economy-based explanation, it must have been political factors, i.e. the political tensions between the U.S. and Turkey over issues like FETÖ, the Syrian war, the S-400 agreement, and the Brunson case, that were behind the financial attacks and hence the severe depreciation of the lira. ${ }^{45}$ In such a sensitive environment, tensions between the U.S. and Turkey and the strengthening of an
CNBC news highlights the economic troubles of Turkey as traders work on the floor of the New York Stock Exchange (NYSE) on August 13, 2018 in New York City, U.S.

EDUARDO MUNOZ ALVAREZ / Stringer 
anti-Turkey stance of Western media outlets at large in tandem, unsettled foreign investors regarding Turkey. Particularly a tweet posted by the U.S. President Donald Trump on August 10 attacking the lira directly, alongside the distortion by some media outlets of President Erdoğan's August 12 statement regarding financial markets in such a way that, foreign currencies in Turkey would mandatorily be converted to the lira when such a move was clearly out of the question, played into the hands of speculators. Taking advantage of the opportunity created by such an atmosphere of rising uncertainty and anxiety, financial speculators tried to increase their gains by betting against the lira.

It is well known that the U.S. has been using its economic and financial power as a weapon against many countries in recent years, including China, Russia, Mexico, Canada, Turkey, and Iran, in the form of protectionist measures ${ }^{46}$, economic/financial sanctions, and attacks against national economies and even national currencies. This has often been conducted through tweets posted by Trump himself, such as the one attacking the lira directly, causing anxiety in financial markets, and triggering capital outflows and the devaluation of the lira.

\section{Reducing Economic Fragilities in Rough Seas}

In the aftermath of the GFC, a significant portion of the liquidity (amounting nearly to $\$ 13$ trillion $)^{47}$ that was injected into the financial markets by the four central banks (i.e., the Fed, ECB, BoJ, and BoE) flowed to developing countries, including Turkey, in search of high returns. In an environment where global liquidity was abundant and global interest rates were considerably low, and where lira-nominated fund-pool was relatively shallow and borrowing costs were relatively high, Turkish companies were inclined to borrow in foreign currencies such as the U.S. dollar and euro. While net short-term position of Turkish firms in general in terms of foreign currency exposure has remained positive, historically low interest rates encouraged some firms to borrow in foreign currencies excessively as they ignored exchange rate risk and diminished the stamina of the Turkish economy to external shocks.

At this point, one should underscore that around 2014 the overall monetary policy stance of the AK Party government changed significantly, from a highly welcoming and accommodating approach to foreign capital, to a more or less balanced one. ${ }^{48}$ From that time on, the government has adopted a monetary policy understanding that is friendlier to the real sector, exporters, and households in general, and tried to limit the massive influence of financial markets on the TCMB, which had already been implementing a more balanced monetary policy since 2010. In earlier years, when global liquidity used to abound for the most part, the government had not tried to regulate and limit the in- 
flowing foreign capital to Turkey. Particularly in 2010 and 2011, when massive amounts of foreign capital were flowing into Turkey, this no-action attitude resulted in record-breaking current account deficits. Moreover, the government had a total hands-off approach to the extremely strict monetary policy implemented by the TCMB. Particularly between 2004 and 2008, the TCMB pursued an incredibly strict monetary policy with policy interest rates averaging 21.3 percent when average inflation rate was just 9.1 percent (note that this was happening during global abundance of liquidity). General monetary policy stance was no different in the whole 2002-2009 period with high levels of real interest rate.

This overall excessively welcoming and accommodating approach to foreign capital between 2002 and 2014 resulted in the overvaluation of the lira to the order of 60 percent and massive expansions in current account deficit. Had the government tried to limit the inflow of foreign capital and sterilized a good portion of the incoming U.S. dollars during this period, Turkey would have been in a better position today, both economically and politically. First, the lira would not have been overvalued that much, if not overvalued at all, and the Turkish manufacturing sector would have grown bigger. Second, Turkish exports would have increased more and the current account deficit would not have expanded as much. Thirdly, Turkey would have been much more resilient against the financial attacks it has endured in recent years.

Turkey has also been criticized on the grounds that it invested considerably in sectors with relatively low productivity and few export opportunities, such as energy and construction/transportation during the period of abundant and cheap liquidity. ${ }^{49}$ While having some merits from a short-term standpoint, this criticism fails to acknowledge the positive externalities and indirect productivity increases resulting from infrastructure improvements in sectors such as energy and real estate. This point is particularly relevant for Turkey, since it had to focus more on energy and infrastructure investments, because of considerably insufficient and lackluster performance in these fundamental sectors, which constitute the "physical base" of economic development. These investments, which should have been started in the 1960s and spread out over forty years, had to be squeezed into a short period, resulting in directing an important part of the financial resources towards these sectors in the 2000s. A good portion of the national savings went to the construction sector in the 2000s, because 


\section{To the economy by slowing down inflation and the current account deficit, the government has decided to implement a more stringent fiscal policy than in the previous years}

of its high yields and the dearth of other investment opportunities, a situation which is a logical extension of the infrastructural necessity. It should also be noted that rapid expansion, high returns, and rising prices in the construction sector did not amount to a real estate bubble, but a markedly delayed correction, which resulted in the maturation of the Turkish construction industry.

The era of global liquidity abundance more or less came to an end as the Fed changed its monetary policy stance slowly but surely, and started to raise policy interest rates at varying intervals after 2014, before tentatively increasing it to an extent in 2019 as economic concerns start to accumulate. In addition, international investment appetite for developing countries declined sharply because of the global uncertainties fueled by trade wars and geopolitical risks. This meant that the party was over as capital inflows to emerging economies slowed down considerably, local currencies depreciated markedly against the U.S. dollar, and borrowing costs in foreign currencies increased to an extent. ${ }^{50}$ Companies engaging in long-term investments by piling up debts in foreign currencies and without foreign-currency revenues through exports saw their balance sheets deteriorate more or less with the turn in the tide of global risk appetite.

While it is obvious that fiscal discipline is critical for macroeconomic stability, a debt level as low as 28 percent could be regarded as ultraconservative as it significantly falls below 60 percent of the relevant Maastricht criterion. Therefore, it could have been better for the Turkish government to borrow somewhat more and raise the debt level to around, say, 40 percent during the "good times" of abundant liquidity and ultra-low interest rates to put that extra liquidity into good use in "rainy days," when the cost of borrowing is high, and the real sector was having difficulty paying their debts. In this way, the government could have been in a better position to relieve the markets in times of financial turbulence.

On the other hand, in an effort to mitigate exchange-rate risks, the government could have prevented companies with no or insufficient foreign-currency revenues from taking on (excessive) debts in foreign-currencies in a timelier manner, just as it stepped in to protect households and the financial system itself in 2007 and hindered banks from extending mortgage loans in foreign currencies. The idea of such a regulation began to emerge only in 2016. Moreover, more selective and restrictive regulations with regards to capital inflows could have been implemented and the U.S. dollar could have been sterilized, hence 
the overvaluation of lira could have been averted in the period of global liquidity abundance. In addition, the (remaining) foreign capital flowing to Turkey could have been channeled towards sectors with higher potential in terms of productivity gains and export revenues through selective industrial policies, especially between 2010 and 2014 .

Although Turkey was able to successfully deal with many of its macroeconomic problems after the 2000-2001 crisis, it has not been able to find a definitive solution to the dollarization problem, which took root in the high-inflation era between 1971 and 2004 and reflected the scarcity of different investment opportunities. Although dollarization decreased considerably during the last decade as a direct result of relatively low levels of inflation rate and macroeconomic/financial stability, it first trended upwards and then accelerated thanks to the exchange rate shock in May-August 2018 as domestic investors increased their foreign currency demand significantly. Although the lira appreciated considerably against the U.S. dollar and recouped a large part of the earlier losses and volatility in the exchange rate markets declined considerably after October 2018, dollarization intensified further, reflecting worries of the domestic investors regarding the exchange rate markets. Moreover, as highly unconventional as it may sound, scaremongers in the social media regarding the future value of the exchange rate also contributed to the dollarization in Turkey.

Turkey needs to reduce dollarization considerably for the monetary transmission mechanism to function properly. To do this, on top of everything else, inflation rate should be decreased to a reasonable level and macroeconomic/ financial stability should be achieved. Secondly, regulating the selling, renting, and leasing of transactions denominated in foreign currencies will also help in the mitigation of dollarization. Thirdly, increasing the number of investment opportunities may help lessen the appeal of dollarization, since the dollarization tendency emanates mostly not from common people but big corporates and investors in Turkey, as is the case in many other countries.

After the currency shock the New Economic Approach and New Economic Package (NEP), announced by Treasury and Finance Minister Berat Albayrak, put forward the medium-term priorities and aims of economic governance and fiscal policy. ${ }^{51}$ As outlined in the NEP, the main goal of the economy management until 2020 is to rebalance the economy by repairing the partial damage and to achieve macroeconomic stability, first and foremost by reducing inflation rate and current account deficit to reasonable levels. ${ }^{52}$ The NEP is a medium-term dynamic program based on the three principles of "balance, discipline, and change" with realistic targets. The NEP, on the one hand, declares that fiscal discipline, which is instrumental in the way of decreasing inflation rate and current account deficit and of economic rebalancing, will be maintained as before. On the other hand, it aims at planting the seeds of 


\section{For the last few years, on the other hand, AK Party governments have made considerable strides in industrial policy and accelerated incentives and investments in order to avoid premature deindustrialization, boost high value-added domestic production, and deepen and diversify domestic energy resources}

France, and 98 percent for Spain. The average of this ratio for the Euro area is more than three times that of Turkey's. A similar, albeit less pronounced, picture emerges when we look at the developing countries. Here, some of the ratios are 83 percent in Brazil, 71 percent in India, 54 percent in Malaysia, and 47 percent in China. Turkey has fiscal space to support promising firms and industries, while maintaining fiscal discipline.

Turkey's external debt level of is also quite manageable, though it is not as low as its public debt level. It should be noted that the external debt level is not to be minimized, but to be optimized, since its level shows both the extent of investors' interest in the country and of the capacity of the country to pay off its debt. Therefore, the vitality and growth performance of the country should be taken into account when assessing the sustainability of the external debt load. When these points are considered, it becomes apparent that the external debt level is certainly sustainable. The gross external debt-to-GDP ratio for Turkey stood at 56.7 percent as of 2018. While this ratio declined steeply, from 54.8 to 38.0 percent between 2002 and 2006, it averaged 38.4 percent with little fluctuation between 2006 and 2013, thanks to a strong economic growth performance along with a strict monetary policy and global liquidity abundance (hence the overvalued lira), which together caused the denominator (GDP in dollars) of the ratio to rise much faster than the numerator (external debt in dollars). During this period, the gross external debt stock increased from 208.0 to 392.8 billion dollars. However, between 2013 and 2018, this ratio increased sharply from 41.3 to 56.7 percent thanks to the reversion of the earlier trend, though gross external debt stock increased only from $\$ 392.8$ to $\$ 444.9$ billion. ${ }^{56}$ In this period, Turkish lira lost a great deal of value against the U.S. dollar, decreasing the denominator of the ratio to a great extent, despite strong growth performance (except in 2018) and strict monetary policy. This ratio is considerably higher in most industrialized countries than in Turkey. For example, the ratio is 143 percent for Germany ${ }^{57}, 216$ percent for France ${ }^{58}$ and 307 percent for the United Kingdom. ${ }^{59}$ On the other hand, while there are some developing countries with higher gross external debt ratios than Turkey, this ratio is somewhat lower in many developing countries. For example, the ratio 
While the Turkish economy performed close to its potential in times of political stability, it fell considerably short of its potential during the periods of political instabilities is 36 percent for Brazil, ${ }^{60} 37$ percent for Indonesia, 38 percent for Mexico, 56 percent for Argentina, ${ }^{61}$ and 65 percent for Malaysia. ${ }^{62}$

One critical factor for a country regarding gross external debt is the capacity of that country to pay off its short-term external debt. This

capacity is particularly high for Turkey, since nonfinancial firms' foreign exchange assets ( $\$ 94.2$ billion) exceed their short-term foreign exchange liabilities ( $\$ 89.2$ billion) by $\$ 5$ billion as of January $2019 .{ }^{63}$ Moreover, the Turkish financial industry is in rather a good position and well-hedged in terms of foreign exchange position, such that the Turkish financial industry has around 5 billion lira surplus of net foreign exchange position as of December 2018, according to the Turkish Banking Regulation and Supervision Agency (BDDK). ${ }^{64}$

Economic policies of early AK Party governments achieved significant successes in strengthening the public finance and restructuring the banking system. Thanks to the strictly-implemented comprehensive reforms on public finance and financial system, the Turkish economy overcame the GCF with relatively little damage and bounced back rapidly. However, the highly liberal and finance-centric economic policy approach produced some important side effects such as premature deindustrialization. Due to reasons mentioned above, in the wake of the GFC, Turkey failed to implement real sector-oriented long-term structural reforms to reduce its external dependence on intermediate goods and energy. This external dependence, in turn, has disrupted current account balance considerably and rendered the real sector less resilient to the external shocks. Moreover, an excessively overvalued lira and a non-selective, ineffective, and inadequate incentive system as part of an industrial policy, has hindered the development of high value-added products.

For the last few years, on the other hand, AK Party governments have made considerable strides in industrial policy and accelerated incentives and investments in order to avoid premature deindustrialization, boost high value-added domestic production, and deepen and diversify domestic energy resources. There are two main reasons behind Turkey's transition to a more developmentalist approach in terms of economic policy. First, in the post-GFC period, the axis of the global economic order has been shifting, slowly but surely, from a liberal to a more protectionist one. This paradigm shift has produced a friendlier environment for developmental policies within which domestic industries are protected and supported. Second, the Turkish economy needs a structural transformation centered on manufacturing to avoid the middle-income trap 
and eliminate the current account deficit problem. Within this framework, a developmentalist approach is highly promising in terms of responding to Turkey's long-term economic needs, though there are some policy distortions to be resolved and policy experiences to be gained along the way.

\section{Conclusion}

Turkey is a country that has on average not yet been able to fully achieve its economic potential. While the Turkish economy performed close to its potential in times of political stability, it fell considerably short of its potential during the periods of political instabilities emanating from intermittent military coups, which considerably disrupted politics and the very fabric of the society, coalition governments with markedly weak governing capacities, and internal crises, which paralyzed politics and bureaucracy. In the aftermath of the 2000-2001 financial crisis, the Turkish economy thrived and expanded tremendously towing much to the continuous political stability achieved after the 2002 general elections, especially until 2013.

The year 2013 was a critical turning point for Turkey. Internal and external shocks such as the Gezi Park events, the December 17-25 “judiciary" coup attempt, the deepening Syrian war, terrorist attacks particularly by the PKK and Daesh, financial attacks and economic manipulations, the markedly strained relations with the Western countries, and most importantly, the military coup attempt of July 15, 2016, all diverted Turkey's time and energy away from the structural reforms needed to break the middle-income trap. In addition, the diminution of the global risk appetite towards developing countries such as Turkey had adverse effects on the Turkish economy. All these developments forced the Turkish government to involuntarily postpone the resolution of various structural problems such as the low share of high-tech products in the manufacturing industry, high dependence on intermediate goods for imports, a high level of current account deficit, and around 10 percent of long-term unemployment rate. They also slowed down long-term productive investments by increasing uncertainties and reducing investors' confidence.

As a response to the external and internal shocks suffered, the government implemented a countercyclical fiscal policy and exerted considerable effort to keep the economy on track via stimulus packages and various supports to the real sector after 2013, without sacrificing budget discipline. Thanks partly to these efforts, but most importantly due to the dynamism of the real sector, the Turkish economy has been able to maintain its strength and vigor.

In 2018, the Turkish economy suffered a severe financial attack, accompanied by an increasingly hostile approach by Western media outlets., This resulted 
For the Turkish economy to write a new success story, Turkey needs to implement smart industrial policies that prioritize high-value added product groups and sectors in a severe depreciation of the Turkish lira, significantly higher inflation and interest rates, and economic stagnation in Turkey. As a response to these economic challenges, the government focused firstly on decreasing inflation rate and keeping budget discipline in an effort to achieve macroeconomic stability.

To render the Turkish economy more resilient to internal and external shocks, Turkey needs to enact real sector reforms, such as strengthening the risk management mechanisms of the real sector, developing financial alternatives that enable SMEs to move more towards capital markets rather than the banking system for access to finance, and reducing the reliance on medium- and high-tech imported intermediate goods in manufacturing. This necessity will presumably be more and more relevant in the short and long term thanks to intensifying geopolitical risks, trade wars and political uncertainties in the world at large, along with the probable slowing-down of the global economy.

Last but not least, for the Turkish economy to write a new success story, Turkey needs to implement smart industrial policies that prioritize high-value added product groups and sectors with greater export potential through a deep bureaucratic capacity that pursues coherent, predictable and flexible policies, along with bold entrepreneurs and investors, who want to have a share in the development of the country.

\section{Endnotes}

1. Nurullah Gür and Şerif Dilek, "İç ve Dış Şoklar Kıskacında Yeni Ekonomi Hikâyesini Arayan Türkiye [Turkey's Quest for New Economy Policy under External and Internal Shocks]," in Ramazan Akkır and et al. (ed.), AK Parti ve Yükselen Türkiye [AK Party and Rising Turkey], (İstanbul: Kadim, 2019), pp. 133-161.

2. Nurullah Gür, "Is Volatility in the Turkish Lira Driven by Speculative Attacks?" TRT World, (August 17, 2018) retrieved from https://www.trtworld.com/opinion/is-volatility-in-the-turkish-lira-drivenby-speculative-attacks--19623.

3. Mevlüt Tatlıyer, "24 Haziran'a Doğru Türkiye Ekonomisini Doğru Anlamak [Understanding the Turkish Economy Correctly Towards the 24 June]," SETA Perspektif, No. 203, (June 2018), retrieved from https:// setav.org/assets/up loads/2018/06/203.-24-Haziran\%E2\%80\%99a-Dog\%CC\%86ru-.pdf.

4. "Bankacılık Düzenleme ve Denetleme Kurulu [Banking Regulation and Supervision Agency] (BDDK), Türkiye Istatistik Kurumu [Turkish Statistical Institute] (TÜiK)," and the authors' own calculations.

5. TÜiK and the authors' own calculations.

6. Nurullah Gür, Sadık Ünay, and Şerif Dilek (ed.), Kuruluşundan Bugüne AK Parti: Ekonomi [AK Party from Establishment to Today: Economy], (İstanbul: SETA, 2018).

7. "News Release: G20 GDP Growth (Quarterly National Accounts)," OECD, Paris, France, (June 12, 2019), retrieved from https://www.oecd.org/sdd/na/G20-GDP-Eng-Q118.pdf. 
8. Ziya Öniş, "Domestic Politics versus Global Dynamics: Towards a Political Economy of the 2000 and 2001 Financial Crises in Turkey," Turkish Studies, Vol. 4, No. 2 (2003), pp. 1-30.

9. Sadık Ünay, “Düzenleyici Devletten Kapsamlı Kalkınmaya: AK Parti Dönemi Türkiye Ekonomisi [From Regulatory Government to Comprehensive Development: Turkey's Economy During the AK Party Period]," in Nurullah Gür, Sadık Ünay and Şerif Dilek (ed.), Kuruluşundan Bugüne AK Parti: Ekonomi [AK Party from Establishment to Today: Economy], (İstanbul: SETA, 2018).

10. "Krizden İstikrara Türkiye Tecrübesi [The Turkey Experience From Crisis to Stability]," BDDK, Ankara, Turkey, (April 3, 2010) retrieved from https://www.bddk.org.tr/ContentBddk/dokuman/duyuru_0395_ 02.pdf; Guzin G. Akin, Ahmet F. Aysan, and Yıldıran Levent, "Transformation of the Turkish Financial Sector in the Aftermath of the 2001 Crisis," in Ziya Öniş and Fikret Şenses (ed.), Turkey and the Global Economy: Neo-Liberal Restructuring and Integration in the Post-Crisis Era, (New York: Routledge, 2009), pp. 73-100.

11. Mevlüt Tatlıyer, “Enflasyon Neden Yükselir, Nasıl Düşer?: Türkiye Örneği [Why Does Inflation Rise, How Does It Fall?: The Turkish Case]," Uluslararası Yönetim Iktisat ve Işletme Dergisi, Vol. 12, No. 30 (2016), pp. 1-20.

12. Nurullah Gür, "The Role of the State in the Turkish Economy," in Ahmet Faruk Aysan, Mehmet Babacan, Hatice Karahan, and Nurullah Gür (ed.), Turkish Economy, (London: Palgrave Macmillan, 2018), pp. 15-37.

13. Mevlüt Tatlıyer and Nurullah Gür, "Büyüme ve Refah Dostu Bir Maliye Politikasına Doğru [Towards a Monetary Policy Friendly to Growth and Welfare]," SETA Analiz, No. 181 (December, 2016) retrieved from https://setav.org/assets/uploads /2016/12/Analiz181.pdf.

14. Ziya Öniş and Caner Bakır, "Turkey's Political Economy in the Age of Financial Globalization: The Significance of the EU Anchor," South European Society and Politics, Vol. 12, No. 2 (May, 2007), pp. 147-164; Devrim Dumludağ, "An Analysis of the Determinants of Foreign Direct Investment in Turkey: The Role of the Institutional Context," Journal of Business Economics and Management, Vol. 10, No. 1 (2009), pp. 15-30.

15. Mehmet Babacan, "Whither an Axis Shift: A Perspective from Turkey's Foreign Trade," Insight Turkey, Vol. 13, No. 1 (2011), pp. 129-157.

16. Gökhan Yılmaz and Dürdane Şirin Saracoğlu, "Technological Change, Human Capital, and Absorptive Capacity: Can Turkey Escape the Middle Income Trap?" METU Studies in Development, Vol. 43, No. 1 (2016), pp. 391-424; Murat A. Yülek, "Thinking About a New Industrial Policy Framework for Turkey," in Aysan, Babacan, Karahan, and Gür (ed.), Turkish Economy, pp. 287-317.

17. Gür, "The Role of the State in the Turkish Economy," pp. 15-37.

18. Mevlüt Tatlıyer, "The 2008-2009 Financial Crisis in Historical Context," in Ümit Hacıoğlu and Hasan Dinçer, Global Financial Crisis and Its Ramifications on Capital Markets, (New York City: Springer, 2017), pp. 3-17.

19. Hatice Karahan, "Türkiye'nin Dış Ticaret Gelişiminde İhracatın Rolü, [The Role of Exports in Expanding Turkey's Foreign Trade]," in Gür, Ünay, and Dilek (ed.), in Kuruluşundan Bugüne AK Parti: Ekonomi, p. 63.

20. "Economic Presentation," Republic of Turkey Ministry of Treasury and Finance, retrieved October 10, 2019, from https://ms.hmb.gov.tr/uploads/sites/2/2019/09/Ekonomi_Sunumu_ING.pdf

21. Nurullah Gür and Mevlüt Tatlıyer, "15 Temmuz'a Giden Sürecin Ekonomi Politiği [The Political Economy of the Period Leading up to July 15]," in Abdurrahman Babacan (ed.), 15 Temmuz Geçmiş-Gelecek [July 15 Past-Future], (İstanbul: Pınar Yayınları, 2018).

22. Hatem Ete and Coşkun Taştan, Kurgu ile Gerçeklik Arasında Gezi Eylemleri [Between Fiction and Reality: The Gezi Protests], (İstanbul: SETA, 2014).

23. Note that the first two of these projects have been completed and are operational as of 2019.

24. Gür and Tatlıyer, "The Political Economy of the Period Leading up to July 15," pp. 216-217.

25. "Gezi Olayları en Büyük Zararı Ekonomiye Verdi [Gezi Events Harm Economy the most]," TRT Haber, (May 27, 2016), retrieved from https://www.trthaber.com/haber/ekonomi/gezi-olaylari-en-buyuk-zarari-ekonomiye-verdi-252949.html. 
26. "17 Aralık Operasyonunun Faturası 49,3 Milyar Dolar [Bill of December 17 Operation Is 49.3 billion USD]," Hürriyet, (December 31, 2013), retrieved from http://www.hurriyet.com.tr/ekonomi/17-aralik-operasyonunun-faturasi-49-3-milyar-dolar-25476066.

27. Barış Balcı, "Merkez Bankası'ndan Çok Sert Faiz Artırımı [Steep Interest Hike from the Central Bank]," Hürriyet, January 29, 2014, retrieved from http://www.hurriyet.com.tr/ekonomi/merkez-bankasindancok-sert-faiz-artirimi-25679037.

28. Yahya Kemal Uzun, “Gezi'yle Alevlenen Faiz Banka Kârlarını Uçurdu, [Bank Profits Gone after the Steep Rise in Interest Rates following Gezi]," Yeni Şafak, (May 26, 2016), retrieved from https://www.yenisafak.com/ekonomi/geziyle-alevlenen-faiz-banka-k\%C3\%A2rlarini-ucurdu-2471511.

29. Murat Yeşiltaş and Necdet Özçelik, When Strategy Collapses: The PKK's Urban Terrorist Campaign, (İstanbul: SETA, 2018). It should be noted that the PKK flagrantly abused the government's "Kurdish Opening" and used the resolution process as a way to equip itself with the ammunition it needed in its "war" against Turkey. Talha Köse, "Rise and Fall of the AK Party's Kurdish Peace Initiatives," Insight Turkey, Vol. 19, No. 2 (2017), pp. 139-165.

30. "Turkey's Fight against DAESH," Ministry of Interior of the Republic of Turkey, (July 2017), retrieved from https://www.icisleri.gov.tr/kurumlar/icisleri.gov.tr/lcSite/strateji/deneme/YAYINLAR/\%C4\%B0\%C3 \%87ER\%C4\%B0K/deas\%20en.pdf.

31. Hatice Karahan and Erdal Tanas Karagöl, “Türkiye'de İhracat: 2013 Yılı Değerlendirmesi, [Turkey's Exports: An Evaluation of 2013]," SETA Perspektif, No. 29 (January, 2014) retrieved from http://file.setav.org/ Files/Pdf/20140204160444_turkiyede-ihracat-2013-yili-degerlendirmesi-pdf.pdf.

32. Bilal Bağış, “Krizlerle Mücadele Stratejisi ve Ekonomi Politikalarında Yeni Dönem [Strategy of Responding to Crises and the New Period in Economic Policies]," in Gür, Ünay, and Dilek (ed.), Kuruluşundan Bugüne AK Parti: Ekonomi, p. 243.

33. "2013'te Ekonomi [The Economy in 2013]," SETA, (January, 2014), retrieved from http://file.setav.org/ Files/Pdf/20140121153345_2013te-ekonomi-pdf.pdf.

34. Projects such as the Trans-Anatolian Natural Gas Pipeline (TANAP), the TurkStream, LNG and natural gas storage facilities, the Akkuyu Nuclear Energy Plant, YEKA projects, and the National Energy and Mine Policy are important examples of intensifying efforts of the government regarding energy sector. With these initiatives, Turkey also showed that it was commercially and financially active in the global energy sector and could form partnerships with different countries, such as Germany on renewable energy, Russia, Japan, and China on nuclear energy, and the U.S., Iran, Qatar, and Azerbaijan on natural gas.

35. Mevlüt Tatlıyer, "The Defender of Democracy: The Turkish People," The New Turkey, (July 27, 2016), retrieved from https://thenewturkey.org/mevluttatliyer/the-defender-of-democracy-the-turkish-people.

36. Sadık Ünay and Şerif Dilek, "July 15: Political Economy of a Failed Coup," Insight Turkey, Vol. 18, No. 3 (Summer 2016); Muhsin Kar and Selim Kayhan, "Resilience of the Turkish Financial System to Failed Coup Attempt," Bilig, No. 79 (Fall 2016), pp. 275-291.

37. Hazal Ateş, "KGF ile Varlık Fonu Iş̧birliği Yapacak [KGF to Cooperate with Asset Fund]," Sabah, (September 17, 2017), retrieved from https://www.sabah.com.tr/ekonomi/2017/09/17/kgf-ile-varlik-fonu-isbirligi-yapacak; "Gov't Extends New TL 25B Loan Package to Support Real Sector," Daily Sabah, (June 13, 2019), retrieved from https://www.dailysabah.com/finance/2019/06/13/govt-extends-new-tl-25b-loanpackage-to-support-real-sector.

38. Nurullah Gür, "Telaşlı Not İndirim Kararı [Flurried Decision to Reduce Rating]," Sabah, (May 5, 2018), retrieved from https://www.sabah.com.tr/yazarlar/perspektif/nurullah-gur/2018/05/05/telasli-not-indirim-karari; Hatice Karahan, "5 Soru: Darbe Girişiminin Ekonomik Yansımaları [5 Questions: Economic Results of the Attempted Coup]," SETA, (July 28, 2016), retrieved from https://www.setav.org/5-soru-darbe-girisiminin-ekonomik-yansimalari/.

39. Mevlüt Tatlıyer, "Bad Journalism against the Turkish Economy," The New Turkey, (August 30, 2018), retrieved from https://thenewturkey.org/bad-journalism-against-the-turkish-economy. 
40. Sadık Ünay and Şerif Dilek, Türk Dış Politikasının Ekonomi Politiği [The Political Economy of Turkey's Foreign Policy], in Burhanettin Duran, Kemal İnat, and Mustafa Caner (ed.), Türk Dış Politikası Yıllığı, (İstanbul: SETA, 2016).

41. Işık Özel, "The Politics of De-delegation: Regulatory (in)Dependence in Turkey," Regulation and Governance, Vol. 6, No.1 (2012), pp. 119-129; Daron Acemoglu and Murat Ucer, "The Ups and Downs of Turkish Growth, 2002-2015: Political Dynamics, the European Union and the Institutional Slide," NBER Working Paper, No. 21608, (October 2015).

42. Mevlüt Tatlıyer, "The Turkish Lira against the US Dollar," The New Turkey, (August 14, 2018), retrieved from https://thenewturkey.org/the-turkish-lira-against-the-us-dollar.

43. Gür and Dilek, "iç ve Dış Şoklar Kıskacında."

44. “Ekonomistler Şaşkın: Doların Yükselmesi için Ortada Hiçbir Ekonomik Gerekçe Yok [Surprised Economists: There Is no Economic Reason for the Rise of the Dollar]," Güneş, (May 23, 2018), retrieved from http://www.gunes.com/ekonomi/ekonomistler-saskin-dolarin-yukselmesi-icin-ortada-hicbir-ekonomik-gerekce-yok-877367.

45. Mevlüt Tatlıyer, "Kurda Yaşananlar ve Finansal Mücadele [The Exchange Rate and Financial Challenges]," Sabah, (August 25, 2018), retrieved from https://www.sabah.com.tr/yazarlar/perspektif/ mevlut-tatliyer/2018/08/25/kurda-yasananlar-ve-finansal-mucadele.

46. As for the protectionist measures, Trump took a step further after Obama and announced that the U.S. renounced the doctrine of globalization, which had been shaped and directed almost singlehandedly by the U.S. for the past 50 years, but was now regarded as the cause for the loss of blue-collar jobs, skewed income distribution, and the miseries of the middle class.

47. Sujata Rao and Dhara Ranasinghe, "Tide about to Turn for Markets as Easy-Money decade Ends," Reuters, (August 16, 2018), retrieved from https://www.euronews.com/2018/08/16/tide-about-to-turnfor-markets-as-easy-money-decade-ends.

48. Mevlüt Tatlıyer, "AK Parti'nin Para Politikası Yaklaşımı [Monetary Policy Approach of AK Party]," in Gür, Ünay, and Dilek (ed.), Kuruluşundan Bugüne AK Parti.

49. Seda Demiralp, Selva Demiralp, and İnci Gümüş, "The State of Property Development in Turkey: Facts and Comparisons," New Perspectives on Turkey, Vol. 55, (November 2016), pp. 85-106.

50. Barry Eichengreen and Poonam Gupta, "Tapering Talk: The Impact of Expectations of Reduced Federal Reserve Security Purchases on Emerging Markets," Emerging Markets Review, Vol. 25, (2015), pp. 1-15.

51. Public economic agencies also tried to take various measures to get through the financial turbulence with the least amount of damage to the economy. For example, the Central Bank of the Republic of Turkey, CBRT, took an important step on August 13 and announced that it would provide all banks with the necessary liquidity in an effort to prevent a possible extraordinary deposit withdrawal and liquidity squeeze. In addition, the TCMB took a bold and critical step and increased policy interest rate by 625 basis points to 24 percent in just one move on September 13. The Banking Regulation and Supervision Agency, BDDK, also raised the equity limits for currency swap transactions in order to mitigate financial speculations against lira.

52. Nurullah Gür, "The Codes of the New Economic Program," The New Turkey, (September 26, 2018), retrieved from https://thenewturkey.org/the-codes-of-turkeys-new-economic-program.

53. Nurullah Gür, "Yeni Ekonomi Programında Akılda Kalanlar [Main Points from the New Economic Program]," Sabah, (September 29, 2018), retrieved from https://www.sabah.com.tr/yazarlar/perspektif/ nurullah-gur/2018/09/29/yeni-ekonomi-programindan-akilda-kalanlar.

54. Gür, "The Codes of the New Economic Program."

55. IMF, General Government Debt, Percent of GDP, retrieved from https://www.imf.org/external/datamapper/GG_DEBT_GDP@GDD/SWE.

56. "Monthly Economic Indicators," Republic of Turkey Ministry of Treasury and Finance, (April 2019), retrieved from https://ms.hmb.gov.tr/uploads/sites/2/2019/04/aylikekonomikgosterge24042019.pdf. 
57. See, "External Debt," Deutsche Bundesbank, (July 16, 2019), retrieved from https://www.bundesbank.de/en/statistics/external-sector/international-investment-position-and-external-debt/-/external-debt-776566.

58. See, "External Debt," Banque de France, retrieved from http://webstat.banque-france.fr/en/browseTable.do?node=5384921; “External Debt and OECD for Nominal GDP," retrieved from https://stats.oecd. org/index.aspx?queryid=60702.

59. See, "UK Economic Accounts Time Series (UKEA)," Office for National Statistics, retrieved from https://www.ons.gov.uk/economy/nationalaccounts/balanceofpayments/timeseries/zaus/ukea; "External Debt and OECD for Nominal GDP," retrieved from https://stats.oecd.org/index.aspx?queryid= 60702.

60. See, "External Debt and World Bank," Banco Central Do Brasil, retrieved from https://www.bcb.gov.br/ en/legacy?url=https:\%2F\%2Fwww.bcb.gov.br\%2Fingles\%2Fnotecon1-i.asp; “External Debt and World Bank," retrieved from https://data.worldbank.org/country/brazil for nominal GDP.

61. See, "External Debt Shocks," World Bank, retrieved from https://data.worldbank.org/indicator/DT. DOD.DECT.GN.ZS?end=2018\&start=1970\&view=chart. The actual ratio here for Indonesia, Mexico, and Argentina is not "External Debt to GDP," but "External Debt to GNI (Gross National Income)."

62. See, "Bank Negara Malaysia," The BNM Quarterly Bulletin, retrieved from http://www.bnm.gov.my/ files/publication/qb/2018/Q4/4Q2018_fullbook_en.pdf.

63. "Finansal Kesim Dışındaki Firmaların Döviz Varlık ve Yükümlülükleri [Foreign Exchange Assets and Liabilities of Nonfinancial Firms]," TCMB, Parasal ve Finansal İstatistikler [Monetary and Financial Statistics], (January, 2019) retrieved from http://www.tcmb.gov.tr/wps/wcm/connect/TR/TCMB+TR/Main+Menu/ Istatistikler/Parasal+ve+Finansal+Istatistikler/Finansal+Kesim+Disindaki+Firmalarin+Doviz+Varlik+ve+Yukumlulukleri/.

64. "Turkish Banking Sector Main Indicators," Banking Regulation and Supervision Agency of Turkey, (December 2018) retrieved from https://www.bddk.org.tr/ContentBddk/dokuman/veri_0023_06.pdf. 